\title{
Phosphorus efficiencies and responses of barley (Hordeum vulgare L.) to arbuscular mycorrhizal fungi grown in highly calcareous soil
}

Received: 5 April 2002 / Accepted: 10 September 2002 / Published online: 31 October 2002

(C) Springer-Verlag 2002

\begin{abstract}
Two experiments were carried out to investigate phosphorus efficiencies and mycorrhizal responsiveness in an improved cultivar (Clipper) and a landrace (Sahara) of barley (Hordeum vulgare L.). In experiment 1, two pot sizes were used to evaluate the effect of soil volume on $\mathrm{P}$ uptake and mycorrhizal responsiveness. In experiment 2, a compartmented ('cross-pot') system was used to monitor ${ }^{32} \mathrm{P}$ delivery by external hyphae of arbuscular mycorrhizal fungi (AMF) to the host plant. Results showed that, irrespective of growth conditions, Sahara had much larger root biomass than Clipper and consequently substantially more $\mathrm{P}$ was allocated to roots in Sahara than in Clipper. Specific root length in Clipper was much longer than in Sahara. Increase in soil volume enhanced percentage root length colonised by AMF, plant growth and $\mathrm{P}$ uptake, and Sahara was more sensitive to changes in soil volume than Clipper. Pot size (soil volume) used to assess responsiveness to AMF by different plant species or genotypes with different root/ shoot ratios might be a confounding factor. Clipper was more responsive to AMF than Sahara in terms of tissue $\mathrm{P}$ concentrations, which is partly related to their differences in root/shoot ratios. However, increases in SPU [specific $\mathrm{P}$ uptake, $\mathrm{mg} \mathrm{P}$ (g root biomass) ${ }^{-1}$ ] caused by AMF were bigger in Clipper, suggesting that AMF played a larger role in $\mathrm{P}$ uptake. In accordance with the larger increase in SPU, Clipper took up more ${ }^{32} \mathrm{P}$ via AMF hyphae than Sahara. The compartmented system using radioactive $P$ might be an alternative approach to directly investigate
\end{abstract}

Y.-G. Zhu (®)

Research Centre for Eco-environmental Sciences,

Chinese Academy of Sciences, 18 Shuangqing Road, Haidian, Beijing 100085, China

e-mail: ygzhu@mail.rcees.ac.cn

Tel.: +86-10-62936940

Fax: +86-10-62923563

Y.-G. Zhu · F.A. Smith · S.E. Smith

Centre for Plant Root Symbioses,

CRC for Molecular Plant Breeding and Department of Soil and Water, The University of Adelaide, Glen Osmond SA 5064, Australia mycorrhizal responsiveness of different plant species or varieties than conventional pot experiments, provided that the same AM fungus is used.

Keywords Arbuscular mycorrhizal fungi ·

Compartmented system - Efficiency · Phosphate uptake

\section{Introduction}

Phosphorus $(\mathrm{P})$ is one of the most important nutrients for plant growth, development and reproduction. In many regions of the world, soil $\mathrm{P}$ is often a factor limiting crop production. To improve the $\mathrm{P}$ nutrition of plants, the traditional approach is to apply large amounts of $\mathrm{P}$ fertilisers to soils. It has been estimated that nearly 30 million tonnes of P-based fertilisers (in terms of $\mathrm{P}_{2} \mathrm{O}_{5}$ ) are applied worldwide every year (International Fertilizer Industry Association 2001). However, the use efficiency of applied $\mathrm{P}$ is generally very low, ranging from $10 \%$ to $30 \%$ in the year applied (McLaughlin et al. 1991). Continuous application of $\mathrm{P}$ fertilisers also increases the risk of P loss from soil to water, causing toxic algal blooms in water bodies (Sharpley et al. 2000). Improving plant uptake of $\mathrm{P}$ from soil is an obvious alternative to the management of low P soils and the enhancement of use efficiency of P fertilisers. P uptake efficiency is usually defined as P uptake per plant, or per unit root biomass or root length. Genetic variations in $\mathrm{P}$ uptake efficiencies have been widely reported in many crops, such as clover (Trolove et al. 1996) and maize (Silva and Gabelman 1992). Plant traits that can influence $P$ uptake efficiency include rhizosphere acidification, root exudation of organic anions, root morphology, uptake kinetics and symbiotic association with mycorrhizal fungi (Smith et al. 1999).

Symbiotic association between plants and arbuscular mycorrhizal fungi (AMF) is widespread and of particular importance in improving plant P uptake efficiency (Smith and Read 1997). The role of AMF in plant nutrition is likely to be important even when plants are genetically 
modified with other traits, such as root exudation of citrate (Lopez-Bucio et al. 2000; Zhu et al. 2001). The beneficial effects of AMF are due mainly to the ability of mycorrhizal fungal hyphae to acquire $\mathrm{P}$ well beyond the limits of the rhizosphere depletion zone (Li et al. 1991). It has been widely reported that responsiveness to (or dependency on) mycorrhizal colonisation, in terms of improved growth and/or P uptake, varies between crop cultivars (Krishna et al. 1985; Koide et al. 1988; Bryla and Koide 1990; Rao et al. 1990; Mercy et al. 1990; Baon et al. 1993; Hetrick et al. 1993; Khalil et al. 1994; Hetrick et al. 1995). Hetrick et al. (1992) observed that modern bread wheat cultivars (released after 1950) have lower mycorrhizal responsiveness than many native grasses, suggesting that modern breeding practices have reduced responsiveness to mycorrhizal symbiosis. However, Koide and his colleagues have argued that modern cultivars of oats and tomato may be more responsive to mycorrhizal associations (Koide et al. 1988; Bryla and Koide 1990). Therefore, there is no general conclusion on whether modern breeding practices under relatively fertile conditions have inadvertently contributed to changes in mycorrhizal responsiveness. Other factors such as inherent plant morphological and phenological traits, and adaptation to infertility based on mechanisms other than mycorrhizal symbiosis will also influence the mycorrhizal responsiveness in wild accessions (Smith et al. 1992).

Plant P uptake is also sensitive to soil volume (i.e. pot size). Otani and Ae (1996) reported that P uptake by buckwheat, groundnut and sorghum increased significantly with increase in soil volume. P uptake was found to be positively correlated with root length in high-P soil, but not in low-P soil or in soil where volume was limited (Otani and Ae 1996). Responsiveness of host plants to AMF colonisation is sensitive to soil $\mathrm{P}$ availability (Smith and Read 1997), and hence possibly to soil volumes of experimental pots. Facelli et al. (1999) have shown that the higher the plant density (relatively small soil volume per individual plant) the lower the mycorrhizal responsiveness. However, the effect of soil volume on plant $\mathrm{P}$ uptake with regards to AMF colonisation has rarely been examined in the past.

The present study is to test (1) whether soil volume could change the mycorrhizal responsiveness of different barley cultivars, and (2) the usefulness of a compartmented ('cross-pot') system in identifying genotypic variation in mycorrhizal responsiveness. We have selected two cultivars of barley (Hordeum vulgare), namely Clipper and Sahara. Sahara is a landrace from Africa, and has been identified as having low P uptake efficiency, high root/shoot ratio and high $\mathrm{P}$ utilisation efficiency as compared with Clipper (Zhu et al. 2002). This study investigated the variation in $\mathrm{P}$ efficiencies (uptake and utilisation) between the two cultivars, the effect of soil volume on $\mathrm{P}$ uptake and mycorrhizal responsiveness of the two cultivars using two pot sizes. The variation in $\mathrm{P}$ uptake mediated by root-distant AMF hyphae was measured with a compartmented system (cross-pot) experiment.

\section{Materials and methods}

\section{Growth medium}

A field soil (grey calcareous soil, Minnipa, South Australia) was used in this study. The soil was collected to a depth of $30 \mathrm{~cm}$, airdried and passed through a $1 \mathrm{~mm}$ sieve. The soil has a $\mathrm{pH}$ of 8.7 (1:5 soil to $0.01 \mathrm{M} \mathrm{CaCl}_{2}$, w/w), and contains $25 \mathrm{mg} \mathrm{kg}^{-1} \mathrm{NaHCO}_{3}-$ extractable P (Colwell 1963), 38.2\% $\mathrm{CaCO}_{3}, 12 \mathrm{mg} \mathrm{kg}^{-1}$ total zinc (aqua-regia-extractable) and $0.78 \%$ organic carbon. The soil was autoclaved to destroy indigenous mycorrhizal fungi. It was supplemented with nutrients as the following compounds (per $\mathrm{kg}$ ): $0.918 \mathrm{~g} \mathrm{Ca}\left(\mathrm{NO}_{3}\right)_{2}, 0.174 \mathrm{~g} \mathrm{~K}_{2} \mathrm{SO}_{4}, 0.185 \mathrm{~g} \mathrm{MgSO}_{4}, 0.4 \mathrm{mg}$ FeEDTA, $2 \mathrm{mg} \mathrm{CuSO} \cdot 5 \mathrm{H}_{2} \mathrm{O}, 0.6 \mathrm{mg} \mathrm{MnSO}_{4} \cdot 4 \mathrm{H}_{2} \mathrm{O}, 0.4 \mathrm{mg}$ $\mathrm{CoSO}_{4} \cdot 7 \mathrm{H}_{2} \mathrm{O}, 0.5 \mathrm{mg} \mathrm{H} \mathrm{BO}_{3}, 0.5 \mathrm{mg} \mathrm{\textrm {H } _ { 2 }} \mathrm{MoO}_{4} \cdot \mathrm{H}_{2} \mathrm{O}$ and $2.2 \mathrm{mg}$ $\mathrm{ZnSO}_{4} \cdot 7 \mathrm{H}_{2} \mathrm{O}$. No additional $\mathrm{P}$ was supplied. Nutrients were supplied in solution and mixed thoroughly by hand.

\section{Experiment 1: pot-size experiment}

This experiment was carried out using PVC pots of two sizes. The small pots had a height of $26 \mathrm{~cm}$ and a diameter of $6.2 \mathrm{~cm}$; the large pots had the same height as the small pots, but a diameter of $10.5 \mathrm{~cm}$. The volume of large pots is roughly three times that of small pots. Each small pot was filled with $950 \mathrm{~g}$ soil, while each large pot was filled with $2,850 \mathrm{~g}$ soil. Half of the pots were inoculated with AMF (see below). Total amounts of nutrients in the larger pots were greater than in smaller pots.

\section{Experiment 2: cross-pot experiment}

This experiment was set up in a compartmented system constructed of PVC tubing $(5 \mathrm{~cm}$ in diameter), with a single side-arm (for illustration of the system, see Smith 2000). The height of the main pot was $25 \mathrm{~cm}$, and the length of the side arm was $6.9 \mathrm{~cm}$. The main pot contained $900 \mathrm{~g}$ soil (i.e. it had same soil volume as the small pots in experiment 1). The side-arm was separated from the main pot by $37 \mu \mathrm{m}$ nylon mesh, which allows the penetration of AMF hyphae but not plant roots. Soil in the side-arm was labelled with ${ }^{32} \mathrm{P}\left(5 \mathrm{MBq} \mathrm{kg}{ }^{-1}\right)$ before potting, a $2 \mathrm{~cm}$ buffer zone was imposed between the nylon mesh and the labelled soil to prevent the movement of ${ }^{32} \mathrm{P}$ from the side-arm to the main pot. The side-arm contained $200 \mathrm{~g}$ soil. Half of the pots were inoculated with AMF (see below).

\section{Experiments 1 and 2: mycorrhizal inoculation}

For the mycorrhizal treatments, the soil was thoroughly mixed with $10 \%$ of inoculum (soil:sand mixture at 10:90 w/w) from a pot culture of Glomus intraradices Schenck \& Smith (obtained from NPI, Utah, USA) grown on sorghum (Sorghum bicolour L.) for 4 months. The inoculum contained approximately 4,000 spores plus root fragments and hyphae per kilogram soil, and no pathogenic microbes were observed in this inoculum. $G$. intraradices is an AM species widely used in experiments. It colonises roots of many plant species rapidly, and has been shown to produce a positive growth response in barley (Baon et al. 1993). Non-inoculated soil received $10 \%$ autoclaved soil:sand mixture (of the same composition as the inoculum material) without any plants being grown in it. In experiment 2, mycorrhizal inoculum was added only to the main pots. The non-mycorrhizal (NM) plants did not receive microbes associated with the complex of soil-AMF inoculum.

\section{Growth conditions}

Seeds of the two cultivars of $H$. vulgare (Clipper and Sahara) were germinated on moist filter paper. Four pre-germinated seeds were sown in each pot. Each pot was thinned to two plants 3-4 days after 
emergence. Each treatment had four replicates. Pots were watered every other day (by weighing) with reverse osmosis water to $14 \%$ water content (w/w) to keep soil moisture content relatively stable. The experiments were carried out in a glasshouse at $25 \pm 2{ }^{\circ} \mathrm{C}$ with ambient light intensity. The plants were harvested 8 weeks after emergence. Experiment 1 was conducted in summer months (December-February), when light intensity was higher than in experiment 2 (September-November).

Plant analysis

At harvest, plant roots were thoroughly washed, and plants were divided into shoots and roots. Root accumulation at the bottom or the side of the pots was not observed. A weighed subsample of fresh root material was removed randomly after the whole root sample was cut into $2-3 \mathrm{~cm}$ pieces; weighed subsamples were used for determination of mycorrhizal colonisation. The remaining material was oven dried at $70^{\circ} \mathrm{C}$ for $24 \mathrm{~h}$, except that in the second experiment, further subsamples of fresh roots and shoots were taken for immediate acid digestion to measure tissue $\mathrm{P}$ concentrations and activity of ${ }^{32} \mathrm{P}$. Dry weights of shoots and roots were recorded. Tissue $\mathrm{P}$ concentration was determined by nitric-perchloric acid digestion in $\mathrm{HNO}_{3}(70 \%): \mathrm{HClO}_{4}(70 \%)$ mixture $(6: 1 \mathrm{v} / \mathrm{v})$ followed by molybdenum-ascorbic acid colorimetry (Hanson 1950). ${ }^{32} \mathrm{P}$ was measured in the same acid digestion solutions in a LKB Wallac liquid scintillation counter.

\section{Mycorrhizal colonisation and root length}

For examination of mycorrhizal colonisation, the subsamples of root material were cleared in $10 \% \mathrm{KOH}$ solution (w/v) and stained using trypan blue (a modification of the method of Phillips and Hayman (1970) omitting phenol from the solutions). Mycorrhizal colonisation was determined by the grid-line intersection method (Giovannetti and Mosse 1980). In experiment 1, subsamples of fresh roots were taken at harvest to measure root length. The gridintersection method was used to determine root length (Newman 1966).

Data analysis

Average specific P uptake (SPU) is expressed as total P uptake (mg $\mathrm{P})$ per gram of dry root mass, and was calculated using Eq. 1:

$\mathrm{SPU}=\frac{\text { Total } \mathrm{P} \text { in plant }(\mathrm{mg})}{\text { root dry weight }(\mathrm{g})}$

Table 1 Biomass production by two barley cultivars grown in pots with two different sizes and with or without arbuscular mycorrhizal fungi (AMF). $M$ Mycorrhizal NM non-mycorrhizal
Mycorrhizal phosphate responsiveness (MPR) is expressed as percentage increase in tissue $\mathrm{P}$ concentrations (either roots or shoots), and was calculated using Eq. 2:

$\mathrm{MPR}=\frac{[\mathrm{P}]_{\mathrm{M}}-[\mathrm{P}]_{\mathrm{NM}}}{[\mathrm{P}]_{\mathrm{NM}}} \times 100$

where $[\mathrm{P}]_{\mathrm{M}}$ and $[\mathrm{P}]_{\mathrm{NM}}$ are $\mathrm{P}$ concentrations with and without $\mathrm{AMF}$ colonisation respectively.

All data were subjected to analysis of variance (ANOVA) using commercially available Genstat.

\section{Results}

\section{Experiment 1}

The percentage root length colonised by AMF was lower in small pots than in large pots for both cultivars, but the two cultivars had similar AMF colonisation percentages (Fig. 1). AMF colonisation slightly reduced root biomass of both cultivars, irrespective of pot size, but did not have a significant effect on shoot biomass (Table 1). Plant shoot and root biomass were significantly higher in large pots than in small pots. Root biomass of Sahara was much higher than that of Clipper, irrespective of AMF colonisation. Both cultivars did not differ significantly in shoot biomass irrespective of AMF colonisation and pot sizes (Table 1). Root/shoot ratios of Sahara were much higher than those of Clipper. Pot size did not have a significant

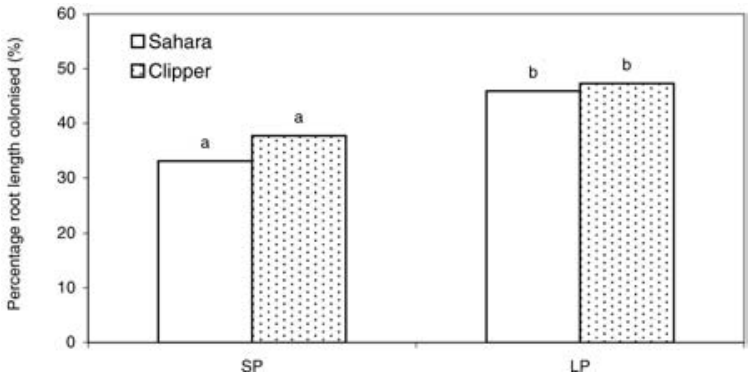

Fig. 1 Mycorrhizal colonisation of two barley cultivars grown in pots of two sizes. SP Small pot, $L P$ large pot

\begin{tabular}{|c|c|c|c|c|c|c|c|}
\hline \multirow[t]{2}{*}{ Cultivar } & \multirow[t]{2}{*}{ Pot size } & \multicolumn{2}{|l|}{ Root } & \multicolumn{2}{|l|}{ Shoot } & \multicolumn{2}{|c|}{ Root/shoot ratio } \\
\hline & & M & NM & M & NM & M & NM \\
\hline Clipper & $\begin{array}{l}\text { Small pot } \\
\text { Large pot }\end{array}$ & $\begin{array}{l}0.52 \\
1.14\end{array}$ & $\begin{array}{l}0.72 \\
1.53\end{array}$ & $\begin{array}{r}4.63 \\
10.26\end{array}$ & $\begin{array}{r}4.90 \\
11.60\end{array}$ & $\begin{array}{l}0.11 \\
0.11\end{array}$ & $\begin{array}{l}0.15 \\
0.13\end{array}$ \\
\hline Sahara & $\begin{array}{l}\text { Small pot } \\
\text { Large pot }\end{array}$ & $\begin{array}{l}1.87 \\
4.39\end{array}$ & $\begin{array}{l}2.50 \\
4.82\end{array}$ & $\begin{array}{l}4.32 \\
9.24\end{array}$ & $\begin{array}{l}3.86 \\
9.99\end{array}$ & $\begin{array}{l}0.44 \\
0.47\end{array}$ & $\begin{array}{l}0.65 \\
0.48\end{array}$ \\
\hline \multicolumn{8}{|c|}{ Analysis of variance } \\
\hline $\begin{array}{l}\text { Cultivar (C) } \\
\text { Pot size (P) } \\
\text { Mycorrhiza }(\mathrm{M}) \\
\mathrm{C} \times \mathrm{M} \\
\mathrm{C} \times \mathrm{P} \\
\mathrm{M} \times \mathrm{P} \\
\mathrm{C} \times \mathrm{M} \times \mathrm{P}\end{array}$ & & $\begin{array}{l}<0.001 \\
<0.001 \\
<0.001 \\
\text { NS } \\
<0.001 \\
\text { NS } \\
\text { NS }\end{array}$ & & $\begin{array}{l}<0.010 \\
<0.001 \\
\text { NS } \\
\text { NS } \\
\text { NS } \\
\text { NS } \\
\text { NS }\end{array}$ & & $\begin{array}{l}<0.001 \\
\mathrm{NS}^{\mathrm{a}} \\
<0.010 \\
<0.050 \\
\mathrm{NS} \\
<0.050 \\
<0.050\end{array}$ & \\
\hline
\end{tabular}

${ }^{\text {a }}$ Not significant 
Table 2 Root length densities and specific root length of two barley cultivars grown in pots with two sizes and with or without AMF

\begin{tabular}{|c|c|c|c|c|c|}
\hline \multirow[t]{2}{*}{ Cultivar } & \multirow[t]{2}{*}{ Pot size } & \multicolumn{2}{|c|}{ Root length density [m $\left.(\mathrm{kg} \text { soil })^{-1}\right]$} & \multicolumn{2}{|c|}{ Specific root length $\left[\mathrm{cm}(\mathrm{mg} \text { root } \mathrm{DW})^{-1}\right]$} \\
\hline & & $\bar{M}$ & NM & $\bar{M}$ & NM \\
\hline Clipper & $\begin{array}{l}\text { Small pot } \\
\text { Large pot }\end{array}$ & $\begin{array}{r}133.9 \\
97.6\end{array}$ & $\begin{array}{l}208.5 \\
152.6\end{array}$ & $\begin{array}{l}23.2 \\
23.0\end{array}$ & $\begin{array}{l}26.3 \\
26.9\end{array}$ \\
\hline Sahara & $\begin{array}{l}\text { Small pot } \\
\text { Large pot }\end{array}$ & $\begin{array}{l}257.7 \\
197.6\end{array}$ & $\begin{array}{l}509.0 \\
318.9\end{array}$ & $\begin{array}{l}12.5 \\
12.2\end{array}$ & $\begin{array}{l}18.4 \\
18.0\end{array}$ \\
\hline \multicolumn{6}{|c|}{ Analysis of variance } \\
\hline
\end{tabular}

${ }^{a}$ Not significant

Table 3 Tissue $\mathrm{P}$ concentrations, total $\mathrm{P}$ uptake $(T P)$ and specific $\mathrm{P}$ uptake (SPU) by two barley cultivars grown in pots with two different sizes and with or without AMF

\begin{tabular}{|c|c|c|c|c|c|c|c|c|c|}
\hline \multirow[t]{3}{*}{ Cultivar } & \multirow[t]{3}{*}{ Pot size } & \multicolumn{4}{|c|}{ Tissue $\mathrm{P}$ concentrations $\left[\mathrm{mg}(\mathrm{g} \mathrm{DW})^{-1}\right]$} & \multicolumn{2}{|c|}{$\mathrm{TP}\left(\mathrm{mg} \mathrm{P}\right.$ plant $\left.^{-1}\right)$} & \multicolumn{2}{|c|}{$\mathrm{SPU}\left[\mathrm{mg} \mathrm{P}(\mathrm{g} \text { root } \mathrm{DW})^{-1}\right]$} \\
\hline & & \multicolumn{2}{|c|}{ Root } & \multicolumn{2}{|c|}{ Shoot } & \multirow[t]{2}{*}{$\mathrm{M}$} & \multirow[t]{2}{*}{ NM } & \multirow[t]{2}{*}{$\mathrm{M}$} & \multirow[t]{2}{*}{ NM } \\
\hline & & $\bar{M}$ & NM & $\overline{\mathrm{M}}$ & NM & & & & \\
\hline Clipper & $\begin{array}{l}\text { Small Pot } \\
\text { Large pot }\end{array}$ & $\begin{array}{l}0.92 \\
1.13\end{array}$ & $\begin{array}{l}0.68 \\
0.81\end{array}$ & $\begin{array}{l}1.58 \\
1.65\end{array}$ & $\begin{array}{l}1.21 \\
1.24\end{array}$ & $\begin{array}{r}7.80 \\
18.34\end{array}$ & $\begin{array}{r}6.40 \\
15.64\end{array}$ & $\begin{array}{l}15.4 \\
16.0\end{array}$ & $\begin{array}{r}9.2 \\
10.2\end{array}$ \\
\hline Sahara & $\begin{array}{l}\text { Small pot } \\
\text { Large pot }\end{array}$ & $\begin{array}{l}1.06 \\
1.28\end{array}$ & $\begin{array}{l}0.91 \\
1.04\end{array}$ & $\begin{array}{l}1.13 \\
1.37\end{array}$ & $\begin{array}{l}0.90 \\
1.02\end{array}$ & $\begin{array}{r}6.86 \\
18.20\end{array}$ & $\begin{array}{r}5.78 \\
15.22\end{array}$ & $\begin{array}{l}3.8 \\
4.2\end{array}$ & $\begin{array}{l}2.3 \\
3.2\end{array}$ \\
\hline \multicolumn{10}{|c|}{ Analysis of variance } \\
\hline $\begin{array}{l}\text { Cultivar } \\
\text { Pot size } \\
\text { Mycorrh } \\
\mathrm{C} \times \mathrm{M} \\
\mathrm{C} \times \mathrm{P} \\
\mathrm{M} \times \mathrm{P} \\
\mathrm{C} \times \mathrm{M} \times \mathrm{P}\end{array}$ & & $\begin{array}{l}P<0 \\
P<0 \\
P<0 \\
P<0 \\
\text { NS } \\
\text { NS } \\
\text { NS }\end{array}$ & & $\begin{array}{l}P<0 \\
P<0 \\
P<0 \\
\mathrm{NS} \\
P<0 \\
\mathrm{NS} \\
\mathrm{NS}\end{array}$ & & $\begin{array}{l}\mathrm{NS}^{\mathrm{a}} \\
P<0 . \\
P<0 . \\
\mathrm{NS} \\
\mathrm{NS} \\
\mathrm{NS} \\
\mathrm{NS}\end{array}$ & & $\begin{array}{l}P<0 . \\
\text { NS } \\
P<0 . \\
P<0 . \\
\text { NS } \\
\text { NS } \\
\text { NS }\end{array}$ & \\
\hline
\end{tabular}

a Not significant

effect on root/shoot ratios except that the root/shoot ratio of NM Sahara in large pots was lower than in small pots. AMF colonisation slightly reduced root/shoot ratios in both cultivars.

Root length densities were significantly lower in large pots than in small pots for both cultivars and Sahara had higher root length densities than Clipper irrespective of pot size and AMF (Table 2). AMF colonisation substantially reduced root length densities for both cultivars with both pot sizes. Clipper had much higher specific root length $\left[\mathrm{cm}(\mathrm{mg} \text { root } \mathrm{DW})^{-1}\right]$ than Sahara and AMF colonisation reduced specific root length in both cultivars (Table 2). Pot sizes did not affect specific root length.

AMF colonisation increased tissue $\mathrm{P}$ concentrations in both cultivars irrespective of pot size (Table 3 ). Tissue $\mathrm{P}$ concentrations were higher in large pots than in small pots irrespective of AMF and cultivar, except Clipper with no AMF. Root $\mathrm{P}$ concentrations of Sahara were higher than those of Clipper, and vice versa for shoot $\mathrm{P}$ concentrations (Table 3). Both cultivars had similar total P uptake. AMF significantly increased total P uptake by the two cultivars, and total $\mathrm{P}$ uptake was much higher in large pots than in small pots (Table 3). Clipper had higher SPU than Sahara and AMF colonisation significantly increased SPU in both cultivars irrespective of pot size (Table 3). Pot size did not affect SPU in either cultivar except that SPU of Sahara with no AMF was slightly higher in large pots than in small pots. Ratios of total root $\mathrm{P}$ to total shoot $\mathrm{P}$ of Clipper were significantly lower than those of Sahara (Fig. 2). Neither AMF nor pot size affected this ratio, except that with Sahara in small pots with no AMF the ratio was higher than with other treatments.

\section{Experiment 2}

The percentages $(\%)$ of root length colonised by AMF were $55 \pm 3.3$ and $50 \pm 3.5 \%$ for Clipper and Sahara, respectively. In this experiment, AMF colonisation reduced shoot and root biomass of both cultivars. Sahara 

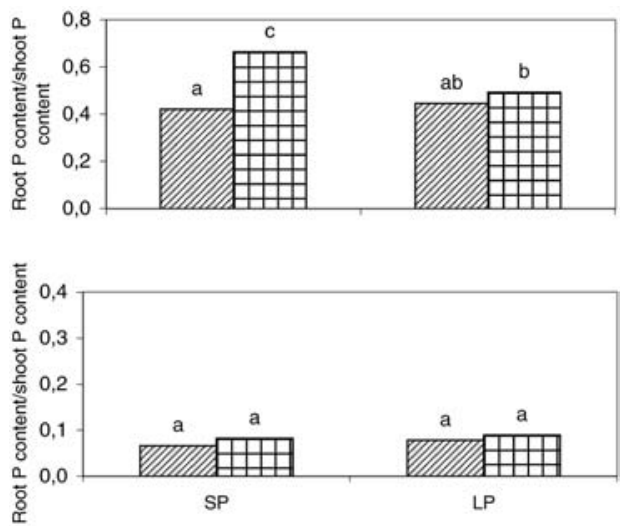

Fig. 2 Root phosphorus (P) content to shoot $\mathrm{P}$ content ratios of two barley cultivars grown with (hatched columns) and without (checked columns) arbuscular mycorrhizal fungi (AMF) in pots of two sizes in experiment 1 . Columns with the same letter are not significantly different at $P<0.05$. Abbreviations as in Fig. 1

Table 4 Biomass production by two barley cultivars grown in compartmented system with or without AMF

\begin{tabular}{|c|c|c|c|c|c|c|}
\hline \multirow[t]{2}{*}{ Cultivar } & \multicolumn{2}{|l|}{ Root } & \multicolumn{2}{|c|}{ Shoot } & \multicolumn{2}{|c|}{ Root/shoot ratio } \\
\hline & $\mathrm{M}$ & NM & $\mathrm{M}$ & NM & $\mathrm{M}$ & NM \\
\hline Clipper & 0.84 & 1.00 & 4.69 & 6.61 & 0.18 & 0.16 \\
\hline Sahara & 1.56 & 2.09 & 4.22 & 6.01 & 0.38 & 0.34 \\
\hline \multicolumn{7}{|c|}{ Analysis of variance } \\
\hline Cultivar (C) & \multicolumn{2}{|c|}{$P=0.001$} & \multirow{3}{*}{\multicolumn{2}{|c|}{$\begin{array}{l}\mathrm{NS}^{\mathrm{a}} \\
P<0.001\end{array}$}} & \multicolumn{2}{|c|}{$P<0.001$} \\
\hline Mycorrhiza (M) & \multicolumn{2}{|c|}{$P<0.001$} & & & \multicolumn{2}{|c|}{ NS } \\
\hline $\mathrm{C} \times \mathrm{M}$ & \multicolumn{2}{|l|}{ NS } & & & \multicolumn{2}{|l|}{ NS } \\
\hline
\end{tabular}

${ }^{\text {a Not significant }}$

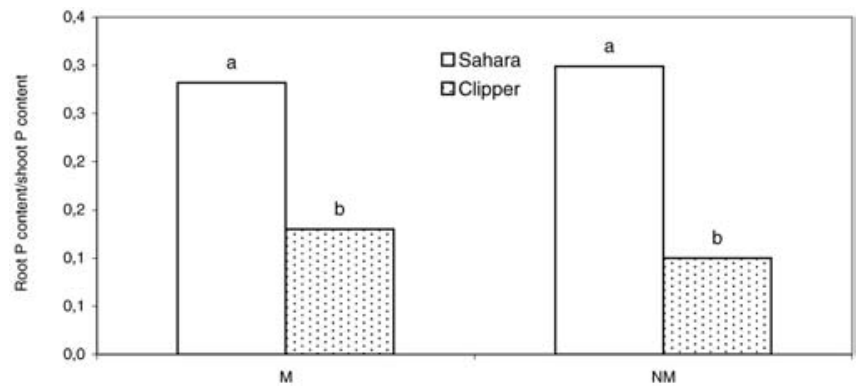

Fig. 3 Root $\mathrm{P}$ content to shoot $\mathrm{P}$ content ratios of two barley cultivars grown with $(M)$ and without $(N M)$ AMF in a compartmented system in experiment 2 . Columns with the same letter are not significantly different at $P<0.05$.

had significantly higher root biomass than Clipper, but both cultivars had similar shoot biomass (Table 4).

Mycorrhizal colonisation significantly increased $\mathrm{P}$ concentrations in shoots and roots of both cultivars and both had similar tissue $\mathrm{P}$ concentrations (Table 5). Mycorrhizal colonisation did not have a significant effect on total $\mathrm{P}$ uptake by either cultivar, but increased significantly the SPU of both (Table 5). Clipper had significantly higher SPU than Sahara. The ratios of root total $\mathrm{P}$ to shoot total $\mathrm{P}$ were much higher in Sahara than in Clipper (Fig. 3). ${ }^{32} \mathrm{P}$ was not detected in NM plants. Activity concentrations, specific activity and total activity of ${ }^{32} \mathrm{P}$ in Clipper were all significantly higher than in Sahara (Table 6).

Table 5 Tissue P concentrations, TP and SPU of the two barley cultivars grown with (M) and without AMF (NM) grown in a compartmented system

\begin{tabular}{|c|c|c|c|c|c|c|c|c|}
\hline \multirow[t]{3}{*}{$\overline{\text { Cultivar }}$} & \multicolumn{4}{|c|}{ Tissue $\mathrm{P}$ concentration $\left(\mathrm{mg} \mathrm{g} \mathrm{DW}{ }^{-1}\right)$} & \multicolumn{2}{|c|}{ TP (mg P plant $\left.{ }^{-1}\right)$} & \multicolumn{2}{|c|}{ SPU $\left(\mathrm{mg}\right.$ P g root $\left.\mathrm{DW}^{-1}\right)$} \\
\hline & \multicolumn{2}{|l|}{ Root } & \multicolumn{2}{|l|}{ Shoot } & \multirow[t]{2}{*}{$\bar{M}$} & \multirow[t]{2}{*}{ NM } & \multirow[t]{2}{*}{$\overline{\mathrm{M}}$} & \multirow[t]{2}{*}{ NM } \\
\hline & $\mathrm{M}$ & NM & $\mathrm{M}$ & NM & & & & \\
\hline Clipper & 1.16 & 0.71 & 1.65 & 1.09 & 8.06 & 7.59 & 11.0 & 7.7 \\
\hline Sahara & 1.11 & 0.85 & 1.48 & 1.09 & 7.69 & 8.09 & 5.4 & 4.2 \\
\hline \multicolumn{9}{|c|}{ Analysis of variance } \\
\hline Cultivar (C) & \multirow{2}{*}{\multicolumn{2}{|c|}{$\begin{array}{l}\mathrm{NS}^{\mathrm{a}} \\
P<0.01\end{array}$}} & \multirow{3}{*}{\multicolumn{2}{|c|}{$\begin{array}{l}\mathrm{NS} \\
P<0.05 \\
\mathrm{NS}\end{array}$}} & \multicolumn{2}{|l|}{ NS } & \multicolumn{2}{|c|}{$P<0.05$} \\
\hline Mycorrhiza (M) & & & & & NS & & \multirow{2}{*}{\multicolumn{2}{|c|}{$\mathrm{NS}$}} \\
\hline $\mathrm{C} \times \mathrm{M}$ & \multicolumn{2}{|l|}{$\mathrm{NS}$} & & & \multicolumn{2}{|l|}{ NS } & & \\
\hline
\end{tabular}

${ }^{a}$ Not significant

Table 6 Activity concentrations $(A C)$, specific activity $(S A)$ and total activity of ${ }^{32} \mathrm{P}$ $(T A)$ in roots and shoots of barley plants colonised by AMF grown in a compartmented system

\begin{tabular}{|c|c|c|c|c|c|}
\hline \multirow[t]{2}{*}{ Cultivar } & \multicolumn{2}{|c|}{$\mathrm{AC}\left[\mathrm{kBq}(\mathrm{g} \mathrm{DW})^{-1}\right]$} & \multicolumn{2}{|c|}{$\mathrm{SA}\left(\mathrm{Bq} \mathrm{mg}^{-1}\right)$} & \multirow[t]{2}{*}{$\mathrm{TA}\left(\mathrm{kBq}\right.$ plant $\left.^{-1}\right)$} \\
\hline & Root & Shoot & Root & Shoot & \\
\hline Clipper & 10.3 & 6.5 & 7.9 & 3.7 & 33.4 \\
\hline Sahara & 2.8 & 2.4 & 2.5 & 1.7 & 14.1 \\
\hline \multicolumn{6}{|c|}{ Analysis of variance } \\
\hline Cultivar (C) & $P=0.06$ & $P<0.05$ & $P<0.05$ & $P<0.01$ & $P<0.001$ \\
\hline
\end{tabular}




\section{Discussion}

Although it had a $\mathrm{NaHCO}_{3}$-extractable $\mathrm{P}$ of $25 \mathrm{mg} \mathrm{kg}^{-1}$, the highly calcareous soil used in this study was still deficient in bioavailable $\mathrm{P}$ for barley growth, since shoot $\mathrm{P}$ concentrations were between $1.0-1.2 \mathrm{mg} \mathrm{g}^{-1}$; whereas optimal $\mathrm{P}$ concentrations for plant growth are normally around 3.0-5.0 mg g $\mathrm{m}^{-1}$ (Marschner 1995). Therefore, increase in plant tissue $\mathrm{P}$ concentrations can be considered as an improvement of plant $\mathrm{P}$ nutrition under the conditions of our experiments.

Clipper is a modern (improved) barley cultivar, whereas Sahara is a landrace (unimproved) from Africa. These two cultivars had very different root/shoot ratios and different patterns of $\mathrm{P}$ allocation between shoots and roots. Both ratios for Sahara were substantially higher than those for Clipper, and are characteristic of species or cultivars adapted to nutrient-poor soil environments (Chapin 1980; Koide et al. 1988; Marschner 1995). Both experiments demonstrated that Sahara had slightly higher total biomass than Clipper, but this was mainly due to its higher root biomass; in fact, Clipper had slightly higher shoot biomass than Sahara. The above differences between cultivars were irrespective of pot size. With larger pots, total plant biomass and $\mathrm{P}$ uptake were greater, which means that nutrient supply, $\mathrm{P}$ in particular, in smaller pots effectively limited the growth of both cultivars. Other effects, such as root-to-root and root-topot contacts may also contribute to the growth effect of pot size. P uptake by plants with small root systems is probably less sensitive to changes in soil volume (Otani and Ae 1996). In the present experiment, $P$ limitation was indeed more of a problem for NM Sahara, as shown by the higher root/shoot ratio in small pots $(0.65)$ than in large pots (0.48). Total P uptake was about the same for both cultivars, but Sahara had much higher amounts of $\mathrm{P}$ allocated to roots and much lower SPU than Clipper. Therefore, in terms of both SPU and P allocation to shoots, Sahara is less efficient than Clipper. The high SPU of Clipper may be at least partly due to the fact that it has much finer roots and twice the specific root length than that of Sahara.

Colonisation by G. intraradices was found to increase tissue P concentrations as well as SPU in both cultivars and in both experiments, which suggested that $G$. intraradices was helping the plant acquire P. In experiment $1, G$. intraradices did not affect shoot biomass significantly, indicating that the apparent amount of carbon spent on AMF or on growing the bigger roots in the NM plants was about the same, and that carbon expenditure on AMF was more economic than expenditure on root growth in terms of improving P uptake. The fact that the increase in shoot $\mathrm{P}$ concentrations did not increase shoot biomass indicated that shoots of both cultivars were under carbon limitation, i.e. there was a carbon drain in both cultivars to 'below ground'. This carbon limitation may stop mycorrhizal plants becoming bigger overall than NM plants under the conditions of experiment 1. G. intraradices reduced both root and shoot

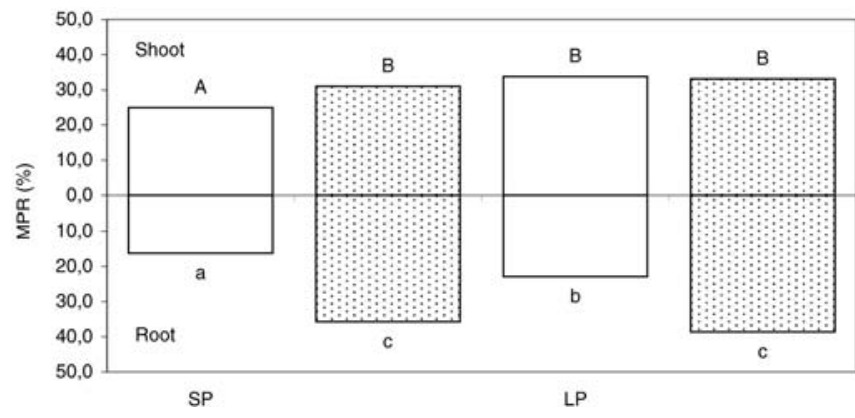

Fig. 4 Mycorrhizal P responsiveness (MPR) (shoot- or root-based) of barley cultivar Sahara (open columns) and Clipper (dotted columns) grown in pots of two sizes in experiment 1 . Columns with the same letter are not significantly different at $P<0.05$. Abbreviations as in Fig. 1

biomass in experiment 2 , which is likely to have been due to the shorter day length and possibly lower light intensity compared with experiment 1 (see Materials and methods). It is expected that under field conditions where plants are unlikely to be C-limited, AMF would be more effective in enhancing plant growth and $\mathrm{P}$ uptake.

The significance of propagule density (the same in both pot sizes) versus total propagules per pot (greater in larger pots) in influencing percentage colonisation needs further study. The outcome will relate to root growth rates, root length density and propagule density, and hence the chance of a propagule hitting a root (Smith et al. 1986). However, the fact that percentage colonisation in each pot size was similar for the two cultivars, despite large differences in root length and specific root length suggests that propagule density was sufficient to achieve maximum colonisation in all cases. Increase in SPU due to $G$. intraradices was bigger with Clipper than with Sahara in both experiments. With Clipper there was a small effect of pot size; the increase in SPU due to AMF was $6.2 \mathrm{mg} \mathrm{P} \mathrm{g}^{-1}$ (67\% increase) in small pots and $5.8 \mathrm{mg} \mathrm{P} \mathrm{g}^{-1}(57 \%$ increase) in large pots (calculated using the data from Table 3). With Sahara there was a larger effect of pot size; the increase in SPU due to $G$. intraradices was $1.5 \mathrm{mg} \mathrm{P} \mathrm{g}^{-1}$ (65\% increase) in small pots, compared with $1.0 \mathrm{mg} \mathrm{P} \mathrm{g}^{-1}$ (31\% increase) in large pots. These decreased effects of $G$. intraradices on SPU in large pots may relate to higher accessibility of P to NM plants (smaller P depletion zone around roots or less overlap in depletion zones), and to improved growth and $P$ nutrition of NM plants. We note again that NM Sahara was apparently more subject to "P stress" in small pots as shown by its higher root/shoot ratio and low tissue $\mathrm{P}$ concentrations. Comparison of the effect of $G$. intraradices on $\mathrm{P}$ nutrition in pots of different sizes is complicated by the different colonisation percentages and possibly densities of extraradical hyphae. In terms of plant P nutrition, the overall result was that Sahara had higher MPR in large pots than in small pots, but for Clipper, there was no effect of pot size on MPR (Fig. 4). Our results also indicated that the increment in total $P$ uptake in response to soil volume increase was bigger for 
Sahara (bigger roots) than for Clipper (smaller roots) irrespective of AMF colonisation (165\% and $140 \%$ for Sahara and Clipper respectively, calculated from data in Table 3). The results suggested that soil volume might sometimes confound interpretation of the effects of AMF on growth of, and $\mathrm{P}$ uptake by, different plant species or genotypes with different root/shoot ratios along with root morphology/architecture and root hairs. Although Clipper had smaller root systems in terms of biomass, its roots were much finer than those of Sahara, and the difference in root diameters would be another factor contributing to the difference in MPR of the two cultivars. Some of the issues regarding measuring the influence of mycorrhizas on plant growth and nutrient acquisition have been thoroughly discussed in Koide et al. (2000) and Smith (2000).

Experiment 2 involved modified small pots (compartmented system) and, importantly, showed directly that the effects of $G$. intraradices on SPU could be related to differences in delivery of $\mathrm{P}$ as ${ }^{32} \mathrm{P}$ from external hyphae in a root-free compartment. The total activity of ${ }^{32} \mathrm{P}$ in Clipper was $33.4 \mathrm{kBq}$ plant $^{-1}$, while in Sahara it was $14.1 \mathrm{kBq}$ plant $^{-1}$. These proportions are very close to those of the AMF-enhanced SPU in Clipper and Sahara: $3.3 \mathrm{mg} \mathrm{P} \mathrm{g}^{-1}$ and $1.2 \mathrm{mg} \mathrm{P} \mathrm{g}^{-1}$ respectively, from data in Table 5. The results suggest that measurement of ${ }^{32} \mathrm{P}$ (or ${ }^{33} \mathrm{P}$ ) uptake from root-free compartments may be used to indicate the roles of AMF in $\mathrm{P}$ acquisition by different genotypes. However, despite the present findings, there remains a possibility that different rooting patterns of hosts may affect the relative abilities of roots and adjacent hyphae to acquire $\mathrm{P}$ - in the present case unlabelled $\mathrm{P}$ from the main compartment of the cross-pot. In other words, with different hosts, the hyphae in the root-free compartment may not always be equally representative of the external hyphae overall even if only one AMF is being tested. Use of compartmented systems to compare different AMF species or isolates in symbiosis with one host plant raises further complications, because different AMF have differences in densities and length of external hyphae and in abilities to transfer labelled $\mathrm{P}$ from rootfree compartments (for discussion, see Smith 2000). To sort out these complications requires more detailed investigations of growth parameters and $\mathrm{P}$ uptake patterns for both roots and AMF in compartmented systems, beyond the scope of the present study. Such investigations will also help in determining the extent to which $\mathrm{P}$ uptake via $\mathrm{AMF}$ results in changes of expression of $\mathrm{P}$ transporter genes in roots (see Liu et al. 1998).

Acknowledgements This project was supported by the Cooperative Research Centre for Molecular Plant Breeding, Australia. We thank Mr. Andrew Barritt for his technical assistance. Y.G.Z. is currently supported by the "Hundred-talent Program" of the Chinese Academy of Sciences.

\section{References}

Baon JB, Smith SE, Alston AM (1993) Mycorrhizal responses of barley cultivars differing in P efficiency. Plant Soil 157:97-105

Bryla DR, Koide RT (1990) Role of mycorrhizal infection in the growth and reproduction of wild vs cultivated plants. II. Eight wild accessions and two cultivars of Lycopersicon esculentum Mill. Oecologia 84:82-92

Chapin FS III (1980) The mineral nutrition of wild plants. Annu Rev Ecol Syst 11:233-260

Colwell JD (1963) The estimation of the phosphorus fertiliser requirements of wheat in Southern New South Wales by soil analysis. Aust J Exp Agric Anim Husb 3:190-197

Facelli E, Facelli JM, Smith SE, McLaughlin MJ (1999) Interactive effects of arbuscular mycorrhizal symbiosis, interspecific competition and resource availability on Trifolium subterraneum cv. Mt. Barker. New Phytol 141:535-547

Giovanetti M, Mosse B (1980) An evaluation of techniques for measuring vesicular-arbuscular mycorrhizal infection in roots. New Phytol 84:489-500

Hanson WC (1950) The photometric determination of phosphorus in fertilisers using the phosphovanado-molybdate complex. J Sci Food Agric 1:172-173

Hetrick BAD, Wilson GWT, Todd TC (1992) Relationships of mycorrhizal symbiosis, rooting strategy, and phenology among tallgrass prairie forbs. Can J Bot 70:1521-1528

Hetrick BAD, Wilson GWT, Cox TS (1993) Mycorrhizal dependence of modern wheat cultivars and ancestors: a synthesis. Can J Bot 71:512-518

Hetrick BAD, Wilson GWT, Gill BS, Cox TS (1995) Chromosome location of mycorrhizal responsive genes in wheat. Can J Bot 73:891-897

International Fertilizer Industry Association (2001) Total fertilizer consumption statistics by region from $1970 / 71$ to $1998 / 99$. http://www.fertilizer.org/stats.htm

Khalil S, Loynachan TE, Tabtabai MA (1994) Mycorrhizal dependency and nutrient uptake by improved and unimproved corn and soybean cultivars. Agron J 86:949-958

Koide RT, Li M, Lewis J, Irby C (1988) Role of mycorrhizal infection in the growth and reproduction of wild vs cultivated plants. I. Wild vs cultivated oats. Oecologia 77:537-543

Koide RT, Goff MD, Dickie IA (2000) Component growth efficiencies of mycorrhizal and nonmycorrhizal plants. New Phytol 148:163-168

Krishna KR, Shetty KG, Dart PJ, Andrews DJ (1985) Genotype dependent variation in mycorrhizal colonisation and response to inoculation of pearl millet. Plant Soil 86:113-125

Li XL, George E, Marschner H (1991) Extension of the phosphorus depletion zone in VA-mycorrhizal white clover in a calcareous soil. Plant Soil 136:41-48

Liu H, Trieu AT, Blaylock LA, Harrison MJ (1998) Cloning and characterization of two phosphate transporters from Medicago truncatula roots: regulation in response to phosphate and to colonisation by arbuscular mycorrhizal (AM) fungi. Mol Plant Microbe Interact 11:14-22

Lopez-Bocio J, de la Vega OM, Guevara-Garcia A, HerreraEstrella L (2000) Enhanced phosphorus uptake in transgenic tobacco plants that overproduce citrate. Nat Biotechnol 18:450 453

Marschner H (1995) Mineral nutrition of higher plants. Academic Press, London

McLaughlin MJ, Fillery IR, Till AR (1991) Operation of the phosphorus, sulphur and nitrogen cycles. In: Gifford RM, Barson MM (eds) Australia's renewable resources: sustainability and global change. Bureau of Rural Resources, Canberra, Australia, pp 67-116

Mercy MA, Shivashankar G, Bagyaraj DJ (1990) Mycorrhizal colonisation in cowpea is host dependent and inheritable. Plant Soil 121:292-294

Newman EI (1966) A method of estimating total length of roots in a sample. J Appl Ecol 3:139-145 
Otani T, Ae N (1996) Sensitivity of phosphorus uptake to changes in root length and soil volume. Agron J 88:371-375

Phillips JM, Hayman DS (1970) Improved procedures for clearing roots and staining parasitic and vesicular-arbuscular mycorrhizal fungi. New Phytol 124:481-488

Rao PSK, Tilak KVBR, Arunachalam V (1990) Genetic variation for VA mycorrhiza-dependent phosphate mobilisation in groundnut (Arachis hypogaea L.). Plant Soil 122:137-142

Sharpley A, Foy B, Withers P (2000) Practical and innovative measures for the control of agricultural phosphorus losses to water: an overview. J Environ Qual 29:1-9

Silva AE, Gabelman WH (1992) Screening maize inbred lines for tolerance to low-P stress condition. Plant Soil 146:181-187

Smith FA (2000) Measuring the influence of mycorrhizas. New Phytol 148:4-6

Smith FA, Smith SE, Reid RJ (1999) Membranes and nutrition: opportunities for integration and progress. In: Gissel-Nielsen G, Jensen A (eds) Plant nutrition - molecular biology and genetics. Kluwer, Dordrecht, pp 291-301

Smith SE, Read DJ (1997) Mycorrhizal symbiosis, 2nd edn. Academic Press, London
Smith SE, St John BJ, Smith FA, Bromley JL (1986) Effect of mycorrhizal infection on plant growth, nitrogen and phosphorus nutrition of glasshouse-grown Allium cepa L. New Phytol 103:359-373

Smith SE, Robson AD, Abbott LK (1992) The involvement of mycorrhizas in assessment of genetically dependent efficiency of nutrient uptake and use. Plant Soil 146:169-179

Trolove SN, Hedley MJ, Caradus JR, Mackay AD (1996) Uptake of phosphorus from different sources by Lotus pedunculatus and three genotypes of Trifolium repens. 1. Plant yield and phosphate efficiency. Aust J Soil Res 34:1015-1026

Zhu YG, Cavagnaro TR, Smith SE, Dickson S (2001) Backseat driving? Most plants depend on arbuscular mycorrhizal fungi to access phosphate beyond the rhizosphere depletion zone. Trends Plant Sci 6:194-195

Zhu YG, Smith FA, Smith SE (2002) Phosphorus efficiencies and their effects on $\mathrm{Zn}, \mathrm{Cu}$, and $\mathrm{Mn}$ nutrition of different barley (Hordeum vulgare) cultivars grown in sand culture. Aust J Agric Res 53:211-216 